\title{
RUSSIA'S NON-PROLIFERATION POLICY AND THE CHALLENGES OF ROGUE PROLIFERATION
}

\author{
Natividad Fernández Sola ${ }^{1}$ \\ Higher School of Economics, Moscow
}

\begin{abstract}
:
This paper analyzes the role of Russia in nonproliferation global efforts, providing a comprehensive overview on Russian nonproliferation, disarmament and arms control policies. With this aim, it will review the main strategic Russian documents on this topic, its participation in nonproliferation regimes and international initiatives, as well as its political approach to the topic. Russia's role in the Iranian and North Korean nuclear challenges as the main current nuclear proliferation concerns is examined. Based on current international engagement and domestic rules and statements, the paper shows that Russia is, at present, a non-revisionist pragmatic actor; but one that is ready to defy the established legal and political order if a threat to its security or interest is present.
\end{abstract}

Keywords: Russia, nuclear proliferation, North Korea, Iran, nuclear posture, NATO.

\section{Resumen:}

Este artículo analiza el papel de Rusia en los esfuerzos globales de no-proliferación, ofreciendo una visión global sobre la no proliferación rusa, desarme y políticas de control de armamentos. Con este objetivo, se van a analizar los principales documentos rusos en este tema, su participación en los regímenes de no proliferación e iniciativas internacionales, así como su postura política hacia este tema. El papel de Rusia en los desafíos nucleares de Irán y Corea del Norte como principales problemas de proliferación actuales es analizado. Basándose en los compromisos internacionales actuales y las normas domésticas y las declaraciones, este artículo muestra que Rusia, es, por el momento, un actor pragmático y no revisionista, pero dispuesto a desafiar el orden político y legal establecido si una amenaza a su seguridad o intereses se presenta.

Palabras clave: Rusia, proliferación nuclear, Corea del Norte, Irán, postura nuclear, OTAN.

Copyright @ UNISCI, 2012.

Las opiniones expresadas en estos artículos son propias de sus autores, y no reflejan necesariamente la opinión de UNISCI. The views expressed in these articles are those of the authors, and do not necessarily reflect the views of UNISCI.

\footnotetext{
${ }^{1}$ Natividad Fernandez is a Visiting Professor at the Higher School of Economics, Moscow. The research for this paper was developed within the framework of the Research Group "Global Governance and the European Union" funded by the Gobierno de Aragón (S-87).

E-Mail: nfernan@unizar.es.
}

http://dx.doi.org/10.5209/rev_UNIS.2012.n30.40700 


\section{Introduction}

On early April $13^{\text {th }} 2012$, North Korea fired a long-range rocket. While the launch from the west coast hamlet of Tongchang-ri failed, the threat remains present. ${ }^{2}$ North Korea had announced it would send a three-stage rocket mounted with a satellite as part of celebrations honoring national founder Kim Il Sung on April $15^{\text {th }}$ and denied the aim was a missile launch. The Pyongyang regime's explanation was that the agreement with the US covered ballistic missiles tests, not the launch of satellites. A third launch by North Korea was foreseen when they broke the negotiations with the US to stop its nuclear program in exchange for food aid. ${ }^{3}$ A negative international reaction followed resulting in the UN Security Council's condemnation of the launch and a call for tighter sanctions on North Korea. ${ }^{4}$

A few days later, India successfully fired an intermediate range ballistic missile (Agni $\mathrm{V})$ to a distance of $5000 \mathrm{~km} .{ }^{5}$ It is part of its retaliatory, no-first use strategic deterrence based on nuclear weapons. According to official views, it represents a deterrence weapon against China, whose Dong Feng IRBM variants are deployed across Tibet, Kunming and Chengdu and are capable of striking major cities, including New Delhi. ${ }^{6}$ However, "official" nuclear powers have reacted nervously as the intercontinental missile can "cover" China and even reach Eastern Europe ${ }^{7}$ while Pakistan fears that it may lead to an eventual escalation of arms race in Asia. The successful test moves India closer to developing a nuclear-capable deterrence against China, joining other nuclear powers which possess similar long-range missiles. Russian analyst B. Volkonsky stated that with the Indian launch, the nuclear weapon is no longer a weapon of dissuasion but a blackmail instrument. ${ }^{8}$ Proliferation of nuclear weapons wobbles the above stability guarantee by the then five nuclear powers. As for the other big proliferation issue, Iran, the international community continues their negotiations with the Islamic Republic regarding the end of its nuclear program. In fact, an important round of talks took place in Moscow, on the $18^{\text {th }}$ and $19^{\text {th }}$ of June 2012.

As for NATO, since there are diverse views on the long-term requirement of U.S. nuclear weapons in Europe, allied leaders meeting in Chicago were unlikely to reach a consensus on major decisions to reshape the Alliance's deterrence and defense posture. This is despite the significant discussions between member states over the past months. ${ }^{9}$ The review document maintains deterrence as the Alliance's main aim with nuclear, conventional and missile defense forces as its means. The role of US nuclear weapons is recognized. Allies concerned by reductions of non-strategic nuclear weapons assigned to NATO will ensure that

\footnotetext{
${ }^{2}$ The Washington Post, 12 April 2012.

3 "North Korea retaliation threat follows international condemnation", Jane's Intelligence Weekly, 18 April 2012.

${ }^{4}$ UN Security Council: Presidential Statement, S/PRST/2012/13 (16 April 2012), supported by China. As a result of the vote at the UNSC, the IAEA announced on 18 April that an inspection planned as part of the Leap Day agreement would go ahead. The resolution was described by North Korean Foreign ministry as "hostile act" and stated his country was no longer bound to the moratorium on nuclear and missile tests. "North Korea retaliation threat follows international condemnation", cit.

${ }^{5}$ Launched on 19 April 2012. Probably India will undertake more tests in the near future to confirm Agni 5's technical parameters. See, "India successfully test-fires long-range missile", Jane's Intelligence Weekly, 20 April 2012.

${ }^{6}$ With the lost of the 1962 border war with China in mind, India now claims its development of nuclear weapons is due to Beijing's burgeoning nuclear arsenal: "India successfully test-fires long-range missile", Nezavisimaya Gazeta, 20 April 2012.

${ }^{7}$ Izvestia, 20 April 2012, p.5.

${ }^{8}$ Kommersant, 20 April 2012, p.8.

9 NATO Deterrence and Defence Posture Review, at http://www.nato.int/cps/en/SID-81FB67529726DAA7/natolive/official texts 87597.htm?mode=pressrelease
} 
all components of NATO's nuclear deterrent remain safe, secure and effective. NATO has also declared its readiness to consider further reduction of non-strategic nuclear weapons assigned to the Alliance. However, this will be done only in reciprocal steps with Russia and once it has been assured the broadest possible participation of the Allies.

This brief overview describes the international framework as an environment where nonproliferation policies are often challenged, making international efforts to promote nonproliferation and the position of big powers increasingly relevant. Russian approach to nonproliferation becomes essential as a balancing and influential power in the main nuclear controversies in the sense that some of the involved countries have a different and less hostile attitude towards Russia than towards the United States.

This paper analyzes the role of Russia in nonproliferation global efforts. It attempts to provide a comprehensive overview on Russian nonproliferation, disarmament and arms control policies. ${ }^{10}$ With its focus on Russia, it can fill-in a research gap that currently exists in the nonproliferation literature. Having this aim, it will review the main strategic Russian documents on this topic, its participation in nonproliferation regimes and international initiatives, as well as its political approach to the topic following government officials' statements, Russian position in international discussions and its role in the Iranian and North Korean nuclear challenges. A detailed analysis on some of these specific issues will be the object of further researches following this comprehensive approach.

Based on current international engagement and domestic rules and statements, the paper shows that Russia is a non-revisionist actor. ${ }^{11}$ But one that is ready to defy the established legal and political order if a threat to its security or interest is present. Russia's pragmatic approach is based on priorities for national interests. The paper also shows the insufficiency of any big power to act in isolation against the global and common nuclear threats.

\section{Russian Strategic Approach to Nonproliferation: National Security Strategy and Russian Nuclear Posture}

Similar to other countries' National Security Strategy documents, Russia's address the issue from a comprehensive approach where all tools (state, private or civilian community tools) can be used to guarantee national security, with or without international cooperation, in a complex and uncertain framework. ${ }^{12}$

Russia's 2020 National Security Strategy (NSS 2020) ${ }^{13}$ avoids any broader discussion on Russia's nuclear policy, confirming only its further reliance on nuclear deterrence and

\footnotetext{
${ }^{10}$ References to nuclear disarmament are included as disarmament, nonproliferation and peaceful uses of nuclear power are the three pillars sustaining the Nonproliferation Treaty (NPT) regime.

${ }^{11}$ Yuan-Kang, W.: "Offensive Realism and the Rise of China", Issues \& Studies, vol. 40, no. 1 (2004), pp. 173201; Snyder, G. H.: "Mearsheimer's World. Offensive Realism and the Struggle for Security", International Security, vol. 27, no. 1 (2002), pp. 149-173; Schweller, "Missed opportunities...", op. cit.; "Bandwagoning for Profit...", op. cit..

${ }^{12}$ Enseñat y Berea, A. F.: “A qué responden las Estrategias de Seguridad Nacional”, IEES, Documento de Opinión, no. 31 (2012).

${ }^{13}$ Signed on 12 May 2009 by President Medvedev, decree No.537. A detailed comment on the NSS 2020, in Schröder, H: "Russia's National Security Strategy", Russian Analytical Digest, no. 62 (June 2009), and in Morales, J: “Russia's New National Security Strategy: Towards a Medvedev's Doctrine?", Real Instituto Elcano, ARI, no.135 (2009).
} 
nuclear parity with the United States. From a defensive and cooperative position, the NSS 2020 states that the country has to prevent global and regional wars and likewise to realize strategic deterrence in the interests of ensuring the country's military security (\$26). Military security can be threatened by policies of foreign countries directed at achieving predominant superiority in the military sphere. Primarily in terms of strategic nuclear forces or by creating a global missile defense system, and policies directed at the proliferation of nuclear, chemical and biological technologies, and the production of weapons of mass destruction, their delivery systems or components ( $\$ 30)$. Two terms seem to be important: the balance of military power - mainly the balance of nuclear power- and the nonproliferation of weapons of mass destruction. Preventing terrorists groups from accessing and obtaining nuclear and/or chemical weapons is seen as important as avoiding ther rise of new nuclear states $(\$ 37){ }^{14}$ Both terms define Russian approach to nuclear nonproliferation that will be, in principle, a multilateral effort and according to International Law. Thus, Russia is in favor of the achievement of new full-scale bilateral agreements on the continued reduction and limitation of strategic offensive arms. However, it still maintains parity with the United States of America in this area, given the deployment of a global missile defense system and implementation of a global lightning strike concept using nuclear and non-nuclear equipped strategic bombers ( $\$ 96)$. It also declares that Russia will participate with other states in the reinforcement of international mechanisms for nonproliferation of nuclear weapons, means of delivery and related goods and technologies (\$94). The promotion of nonproliferation and of a world free from nuclear weapons is the best way to ensure strategic stability and conditions of equal security for all $(\$ 90)$.

Comparing the threats to Russian security from nuclear weapons and nuclear policies with the way to cope with them, one has the impression that, in some ways, the risks analysis made by the NSS 2020 is not completely coherent and that there is a certain disparity between aspirations and resources. The security risks, in defense terms, are mixed with what in fact is only a political aim, the strategic arms balance with the US. But this is a clear consequence of one of the principles guiding the Foreign Policy Concept, adopted in July 2008: ${ }^{15}$ to consolidate Russia as a great power in the international arena. In the same vein, it is dubious that NATO enlargement was, by its very nature, a threat to national security. Both statements reflect the persistence of a Cold War philosophy together with a clear conscience of the new threats to its security. A much clearer security threat is the non-compliance with international arms control. It is to remember that the US denounced the ABM Treaty in 2002, or NATO countries refused to ratify the Adapted Conventional Forces in Europe Treaty. But here again, Russia reacted in a different way depending on the state involved in such non-compliance, as can be seen in the cases of Iranian and North Korean nuclear programs.

In a more specific area, the Russian government adopted, in September 2008, a new Arctic Strategy. ${ }^{16}$ Its main goal is to transform the Arctic into Russia's top strategic base for natural resources by 2020 and preserve the country's role as a leading Arctic power. According to the Strategy, one of Russia's major aims is the establishment of special Arctic military formations in order to protect the country's national interests in various military and political situations. It serves mainly to combat terrorism at sea, smuggling and illegal migration, as well as protect aquatic biological resources. The document underscores its

\footnotetext{
${ }^{14}$ A regime of secure functioning of enterprises, organizations and institutions belonging to the country's military-industrial, nuclear, chemical and nuclear energy complexes is also foreseen in $\$ 40$.

${ }^{15}$ Haas, M: "Medvedev's Security Policy: A Provisional Assessment”, Russian Analytical Digest, no. 62 (August 2009), pp. 2-5.

16 "Osnovy gosudarstvennoi politiki Rossiiskoi Federatsii v Arktike na period do 2020 goda i dalneishuiu perspektivu", at http://www.scrf.gov.ru/documents/98.html.
} 
cooperative character emphasizing the need to preserve the Arctic as a zone of peace and cooperation, and underlining the role of regional bilateral and multilateral cooperation. Consequently, it seems clear that nuclear weapons or materials will stay out of the Arctic area.

The 2010 Russian Military Doctrine develops some of the concepts included in the NSS 2020. Contrary to expectations, it somewhat reduces Russia's reliance on nuclear weapons in its national security policy. ${ }^{17}$ In particular, the New Military Doctrine reduces the role of nuclear weapons by setting stricter criteria for its use. The new criterion for the employment of nuclear weapons is the threat to Russia's very existence, and not only situations critical for national security, as was the case before. ${ }^{18}$ As has been shown, the new shift in Russian nuclear policy has clear indications of being influenced by the US Nuclear Posture Review, and it has not added new missions for its nuclear forces. ${ }^{19}$ Nuclear restraints by the US or Russia changes the terms for bargaining and cause other powers to adjust their nuclear policies when they judge such changes to be in their broader interests. This is an important fact this paper will use later to produce a realist lecture of the Russian nonproliferation policy. In 2009, Russia had a different perception of its security environment and it favored the agreement on the new START as well as some modest changes in its national nuclear weapons posture.

If the 2000 Military Doctrine considered the use of nuclear weapons for regional and large scale wars, the 2010 Military Doctrine ${ }^{20}$ follows the 1993 Doctrine and limits them to global war (at least in the doctrine terms). When the military doctrine was first discussed in October 2009, Russian officials were in favor of a new flexible nuclear doctrine which includes a wide range of potential uses of nuclear weapons, even a preventive nuclear strike on the aggressor and to repel an aggression with the use of conventional weapons not only in a large-scale war but also in regional and even local wars. As previously mentioned, while the final version maintains a nuclear response in the face of a nuclear or conventional aggression, the latter would only be justified against attacks that are "imperiling the very existence of the state". ${ }^{21}$ The New Doctrine keeps the first-use clause, as a nuclear response is possible not only against a nuclear or other WMD attacks but also against a conventional one. According to the Military Doctrine, in order to cope with the task assigned to nuclear weapons, it is important to keep strategic stability and the nuclear deterrence capability at the level of sufficiency. It means the ability to create and perform a tailored deterrence against aggressors under any circumstance. An important note is that high-precision weapons, eventually conventional, also have a strategic deterrence mission. However, there is no reference to tactical roles for nuclear weapons.

This brief review of the Russian strategic texts can draw the conclusion that, even if Russia continues to fear being encircled by enemies, the apparent role of nuclear weapons in national security is more limited than in previous military documents. Russia's 2010 Military

\footnotetext{
17 The same date, February $5^{\text {th }}$, President Medveded signed too "The Foundations of State Policy in the Area of Nuclear Deterrence until 2020", document which has not yet been made public. "The Military Doctrine of the Russian Federation", at www.sras.org/military doctrine russian_federation_2010.

${ }^{18}$ Sokov, Nikolai: "The New 2010 Russian Military Doctrine: The Nuclear Angle", CNS (February 2010) at http://cns.miis.edu/stories/100205 russian_nuclear_doctrine.htm.

19 The NPR was published in April 2010, later than the Russia Military Doctrine, but had been anticipated by President Obama speech in Prague, April 2009. See Sagan \& Vaynman: "Conclusions", The Nonproliferation Review, vol.18, no. 1, especially pp.238-243. The authors outlined also the impact of NPR on the position of non-nuclear weapon states during the 2010 Review NPT Conference.

${ }^{20}$ Military Doctrine was elaborated by a working Group headed by the former chief of the general staff, Yuri Baluevsky.

21 Povdig, Pavel: “Instrumental Influences”, The Nonproliferation Review, vol. 18, no. 1 (2011), p. 47.
} 
Doctrine emphasized the role of conventional forces, especially of high-precision assets, communications and command and control systems; elements in which Russia is usually behind other military powers. This can be interpreted both as a confirmation of Russia's will to modernize the Armed Forces to close the existent gap as well as a contribution in efforts to reduce nuclear weapons globally and domestically. Concerning military reform, in April 2012 President Medvedev announced that it was "practically completed" and the country's military forces must be ready by 2017 to respond to US missiles defense plans in Europe. ${ }^{22}$

On his side, then Prime Minister Putin said one of the main threats to Russian security is nuclear weapons proliferation and thus Russia's foreign policy aims to stop nuclear proliferation in Iran and North Korea. In order to be credible, the country needs to be strong. ${ }^{23}$ As Prime Minister Putin pointed out, the current reality of precision-guided weapons systems, the advent of ballistic missile defenses, the prospect of weapons in the space and cyber-threats of all types makes maintaining strategic stability a much more complex exercise. ${ }^{24}$ For this reason, at the moment he was facing his election as Russian President, Putin promised a largescale military modernization that includes adding 400 intercontinental and submarinelaunched ballistic missiles and eight ballistic missiles submarines within the next ten years. ${ }^{25}$ Even within Russian establishment, the question of whether this massive spending is sustainable is controversial, as Russia's growth prospects have been revised downward during the last year. Moreover, the modernization of the Russian Armed Forces demands close cooperation with Western countries, which can provide resources for this process. Hence, a progressive demilitarization of the Russo-American relations is needed and which will impact on Russia's position concerning nuclear deterrence and on its efforts in nonproliferation.

\section{Russian Participation in International Nonproliferation Agreements and Forums $^{26}$}

From a normative and positivist point of view, Russia's involvement in most international agreements on nonproliferation is both positive and constructive. Russia participates in the main regimes related to nonproliferation: nuclear disarmament, multilateral regimes for nonproliferation of new nuclear states and confidence measures agreements, monitoring and protection of nuclear materials export or traffic and nuclear forensics; formal and informal international regimes and fora.

This involvement is a tool aimed for national interests, improving Russian position in nonproliferation efforts and also as a way to persuade by the force of law and international cooperation. This section considers the main instruments that Russia is part of, in relation to nuclear disarmament and nonproliferation. This is especially with regards to regulations on

\footnotetext{
${ }^{22}$ Until 2020 it is expected Russia to expend at least $2.8 \%$ of GDP. See Moskovskie Novosti, Vedomosti, RBK daily. April 2012.

${ }^{23}$ Putin, Vladimir: "Rusia y el mundo en transformación”, Moskovskie Novosti, 28 February 2012.

${ }^{24}$ Trenin, Dimitri: "Putin's National Security Vision", Carnegie Moscow Center - Carnegie Endowment for International Peace, (March 2012), at http://carnegie.ru/publications/?fa=47273

${ }^{25}$ Ibid. This modernization demands 23 trillion rubles-more than $\$ 750$ billion over a decade-and should also buy Russia 20 multipurpose submarines, 50 surface ships, 100 military spacecraft, 600 aircraft, over 1,000 helicopters, 28 S-400 missile interceptors.

${ }^{26} 1963$ Partial Nuclear Test Ban Treaty, 1968 Nuclear Non-Proliferation Treaty, 1972 Anti-Ballistic Missile Treaty, 1974 Threshold Test Ban Treaty, 1987 Intermediate-Range Nuclear Forces Treaty, 1991 START I, 1993 START II, 1994 United States - Russia mutual detargeting, 1996 Comprehensive Nuclear-Test-Ban Treaty (not into force), 1997 START III, 2002 Strategic Offensive Reductions Treaty, 2010 New START.
} 
nuclear tests, nuclear exports and stockpiles, nuclear smuggling, control on missiles and nuclear forensics. ${ }^{27}$

\subsection{Bilateral Agreements on Nuclear Disarmament}

Russia has engaged in bilateral agreements with the US in order to reduce their respective nuclear arsenals and thus reducing the inherent risk to global security. These reductions were profitable for both sides, considering the maintenance cost of nuclear facilities and the obsolescence of some nuclear weapons and launchers. Moreover, for the Soviet Union, any reduction was advantageous considering its traditional superiority in conventional weapons.

First, the then Soviet Union participated in the Strategic Arms Limitation Talks (SALT I and II, 1969-1972, 1972-1979) with the United States as well as, as the Russian Federation, in the Strategic Offensive Reductions Treaty (SORT 2002) that mandates both parties to mutually decrease strategic nuclear weapons and reserving the right to determine the structure of their strategic offensive arms.

In the nineties, a new series of bilateral negotiations started, resulting in the signature of the Treaties on Strategic Arms Reduction (START I, 1992 and START II, 1997 ${ }^{28}$ ). If SORT did not provide any mechanism for verification, the START treaties were equipped with these mechanisms, providing mutual transparency and security. The new START is the most recent agreement, signed on April $14^{\text {th }}, 2010$. It establishes a limit of 1,550 deployed strategic nuclear warheads and also an aggregate limit of 800 deployed and non-deployed ICBM launchers, SLBM launchers and heavy bombers equipped for nuclear armaments. The timeframe for the implementation of these reductions is seven years after the Treaty's entry into force. ${ }^{29}$ The added value of the bilateral nuclear arms reduction or control is its positive impact on nonproliferation. In fact, many non-nuclear states refused further nonproliferation engagements within the NPT if the big nuclear powers, US and Russia, did not reach an agreement to reduce their nuclear arsenals.

\subsection{Multilateral Engagements on Nonproliferation}

Russia is also a founder signatory of the Nuclear Nonproliferation Treaty (NPT), the most important international regime to avoid nuclear proliferation working on a multilateral basis. ${ }^{30}$ Its indefinite extension of validity was agreed with difficulties in a 1995 revision conference as a package deal, which includes a decision on nonproliferation and disarmament principles and aims, a decision on the reinforcement of treaty revision process and a resolution on the settlement of a zone free from nuclear weapons in Middle East. Among the objectives related with the disarmament was the finishing of a treaty on the complete ban of nuclear tests, the negotiation of a treaty on fissile material production with a verification mechanism, and steady progress towards reduction and finally elimination of nuclear weapons.

\footnotetext{
27 A complete description of all the international engagements adopted by Russia on WMD, at http://www.nti.org/country-profiles/russia/treaties/?page=2.

${ }^{28}$ On 14/7/2002 Russia declares it null and voids it due to US refusal to ratify the Treaty and to US withdrawal from the ABM Treaty.

${ }^{29}$ An analysis of the New Start, in N. Fernandez Sola: "Una respuesta multilateral a la proliferación nuclear: las perspectivas de la conferencia de revisión de 2010 del Tratado de No Proliferación Nuclear", Anuario de Derecho Internacional (2009), pp.319-345. The text of the treaty in http://www.state.gov/t/avc/newstart/c44126.htm .

${ }^{30}$ The treaty was negotiated from 1957 to 1968 and signed in London, Washington and Moscow the $1^{\text {st }}$ July 1969. It entered into force in 1970, 5th March, for a 25 year-period.
} 
Russia is signatory of the 1996 Comprehensive Nuclear-Test-Ban Treaty (CTBT), banning any nuclear weapon test explosion or any other nuclear explosion. ${ }^{31}$ However, as it is well known, the CTBT has not yet entered into force, as it needs the ratification by all states listed in Annex 2 of the Treaty. Among these states, the Democratic People's Republic of Korea, India and Pakistan have not signed, and China, Egypt, Iran, Israel and the US have not ratified. The US and China, the only remaining NPT Nuclear Weapon states that have not ratified the CTBT, released a joint statement declaring that "both sides support early entry into force of the Comprehensive Nuclear-Test-Ban Treaty (CTBT)" and "agreed to work together to achieve this goal", ${ }^{32}$ but neither the United States nor China have ratified the treaty. Under these conditions, one can easily guess the negative perception that countries like Russia have. Evidently, the ratification of the US and China will not imply the one by Iran, but could boost the odds of ratification by Egypt and perhaps Israel.

The CTBT is frequently associated with another key element in the process of nuclear disarmament: a ban of the production of fissile material for anything other than verified peaceful use. The draft Fissile Material Cut-Off Treaty, that would impose a quantitative limit on the amount of nuclear material available for weapons use, together with CTBT are integral components of the nuclear arms control regime and provide the foundation for eventual nuclear disarmament. Russia participates in the negotiations within the Conference of Disarmament and promotes the multilateral framework rather than the bilateral one. ${ }^{33}$

One relevant issue in the international efforts towards nonproliferation is the protection of nuclear materials in order to avoid their use for criminal purposes, compromising international security. There are several legal and informal instruments in place to manage this risk. The main legal multilateral instruments are the International Convention for the Suppression of Acts of Nuclear Terrorism ${ }^{34}$ and the Convention on the Physical Protection of Nuclear Materials of which Russia is a member. The Convention on the Physical Protection of Nuclear Materials was signed by the Soviet Union on May $22^{\text {nd }}, 1980^{35}$ and its amendment on September $19^{\text {th }}, 2008$. It obliges member states to ensure the protection of nuclear material during transport within their territory or on board of their ships or aircrafts.

Russia signed the United Nations International Convention for the Suppression of Acts of Nuclear Terrorism on September $14^{\text {th }}, 2005$ and ratified it on January $29^{\text {th }}, 2007$. The Convention typifies acts such as the possession of radioactive material that causes death or damage to a person, property or environment; the use of these materials or the threat to so, as well as the use of force to obtain this result. Member states engage in cooperation, exchange of information, prosecution on its territory and measures to protect nuclear material. During ratification, Russia made a statement on the unavoidable responsibility of member states for actions under this Convention.

All these elements show the Russian normative constructive approach to multilateral

\footnotetext{
${ }^{31}$ Previously the Soviet Union signed the Treaty for Partial Ban of Nuclear Tests (PTBT) in 1963 and the bilateral (with the US) Threshold Test Ban Treaty in 1974 that established limitations of underground nuclear weapon test.

${ }^{32}$ Statement on 19 January, 2011. The previous one dated from November 17th 2009. See "U.S.-China joint statement: Both sides support early entry into force of the CTBT", at http://www.ctbto.org/presscentre/newsletters/newsletters/us-china-joint-statement-both-sides-support-early-entry-into-force-of-the-ctbt1/

${ }^{33}$ Discussions in the Conference of Disarmament in February and March 2011 where differences emerged in how the starting of negotiations would be accomplished. Russian Foreign Minister expressed concern that parallel disarmament initiatives would degrade the multilateral disarmament system.

${ }^{34}$ UN Convention on 13 April 2005, Res.59/290.

${ }^{35}$ Ratification by the Soviet Union on 25 May 1983 and entry into force for this country on 8 February 1987.
} 
forums on nonproliferation. The Russian position in Nuclear Security summit is the best proof on the country's new attitude and cooperative approach to the problem. Particularly, in the last nuclear security summit in Seoul in 2012, Russia had the opportunity, as described by Rojansky, to show that it has turned the corner from being a nuclear security problem state to being part of the solution. ${ }^{36}$ However, Russia remains reluctant to adopt new control measures considering the almost impossible attack against its nuclear sites or the material's smuggling to be used by terrorists. For economic reasons, the country has not begun the transformation of its facilities (including Navy submarines that use HEU propulsion) using highly enriched uranium to new ones that uses enriched uranium at a lower level in order to reduce the risk of misuse.

Another important aspect in nonproliferation efforts is the coordinated control of exports of nuclear materials or double-use materials and the prevention of nuclear smuggling. Russia is part of the main agencies and agreements on nonproliferation exports control: Zangger Committee, Nuclear Suppliers Group, Missile Technology Control Regime and Wassenaar arrangement. The Zangger Committee, a voluntary regime, was created in 1971. Its main purpose is the drafting a "trigger list" of sources of special fissionable materials and equipment or materials especially designed or prepared for the processing, use or production of special fissionable materials. The informal Zangger Committee published in 1974 a list of items that would "trigger" a requirement for safeguards and guidelines governing the export of those items to Non Nuclear-Weapons States that are not parties to the NPT. Any nuclear supply has to fulfill three conditions: a non-explosive use assurance, an IAEA safeguards requirement and a re-transfer provision (the receiving States have to apply the same conditions when re-exporting these items).

Forty-six nuclear supplier countries, including Russia, that seek to contribute to the nonproliferation of nuclear weapons associated, since 1975, in the Nuclear Suppliers Group (NSG) or "London Group". They implement two sets of guidelines for nuclear exports and nuclear-related exports. The first governs the export of items especially designed or prepared for nuclear use: nuclear material, nuclear reactors and equipment therefore, non-nuclear material for reactors, plant and equipment for the reprocessing, enrichment and conversion of nuclear material and for fuel fabrication and heavy water production, and technology associated with each of the above items. The second set of guidelines governs the export of nuclear-related dual-use items and technologies. ${ }^{37}$ Both aim to ensure that nuclear trade for peaceful purposes does not contribute to the proliferation of nuclear weapons. The NSG requires IAEA safeguards as a condition of supply, with full-scope safeguards as the norm.

In contrast with Zangger Committee members, NSG members are not required to be part to the NPT but they must all adhere to instruments that contain equally binding commitments. Even if serving the same objective, the NSG and the Zangger Committee differ in the scope of their trigger lists of especially designed or prepared items and in the export conditions for items on those lists. The NSG arrangement covering exports of dual-use items is a major difference between the NSG and the Zangger Committee as dual-use items fall outside the Zangger Committee's mandate. Despite both international engagements, some transfers of nuclear materials and equipment are not clearly justified except for political reasons.

\footnotetext{
${ }^{36}$ Dalton, T.; Rojansky, M. and Choubey, D: "Securing 'Loose Nukes'”, Wilson Center, CONTEXT (29 March 2012), at http://www.wilsoncenter.org/article/securing-\%E2\%80\%98loose-nukes\%E2\%80\%99.

${ }^{37}$ IAEA document INFCIRC/254; IAEA document INFCIRC/254/Rev1, Part 1 and 2.
} 
Finally, Russia also participates in the arrangement on export controls for conventional arms and dual-use goods and technologies (Wassenaar Arrangement), established in 1995. Currently, there are 40 states that produce or export arms or associated dual-use goods and technologies, and which implement fully effective and rigorous national export controls via national policies that do not permit the sale of arms or sensitive dual-use items to countries whose behavior is a cause for concern. The purpose of the arrangement is to contribute to regional and international security by promoting transparency with regards to the transfer of conventional arms and dual-use goods and technologies, and enhancing cooperation to prevent the acquisition of armaments and sensitive dual-use items for military end-uses if a particular situation is or becomes a cause for serious concern to the participating states.

The Russian Federation is an essential part of the Global Partnership Against the Spread of Weapons and Materials of Mass Destruction. Originally, the Global Partnership Program that was set up in 2002 focused on countries of the former Soviet Union; but the Partnership expanded its scope of activities globally in 2008. Even today, a problem subsists in the Moldovan region of Transnistria where uranium smuggling is common. Recognizing it as an important multilateral initiative which supports the Nuclear Security Summit goals and reduce the risk of WMD terrorism through cooperative capacity building on specific projects, the G8 leaders at Deauville Summit extended the Partnership, which now comprises 24 member states, beyond 2012.

Concerning missile proliferation, Russia negotiated with the United States on the AntiBallistic Missile Treaty (ABM) as part of the Strategic Arms Limitation Talks. Their idea was that limiting defensive systems will reduce the need to build more offensive weapons to overcome any defense that the other might deploy. The ABM was signed on May 1972 and entered into force on October 1972. The Treaty barred both countries from deploying nationwide defenses against strategic ballistic missiles. It allowed the parties to deploy two fixed, ground-based defenses of 100 missile interceptors each. In a 1974 protocol, the two sides halved the number of permitted defenses. At President G. W. Bush's initiative, the United States withdrew from the ABM on June $13^{\text {th }}, 2002$, claiming that it prevented US development of defenses against possible terrorist attacks or "rogue-state" ballistic missile attacks.

Secondly, Russian Federation (previously the Soviet Union), and other 33 states, belongs to the informal non-treaty association Missile Technology Control Regime (MTCR), established in 1987 to avoid the proliferation of missiles, ${ }^{38}$ unmanned air vehicles and related technologies and, by this way, to limit the risk of proliferation of weapons of mass destruction. The regime's guidelines consist of national control laws and procedures, a twocategory common control list, information sharing on any denied cases, no impediment to national space programs and presumption of denial of any transfer in terms of nuclear weapons delivery systems development and no retransfers without authorization. The parts emphasized the importance of following UN Security Council resolutions 1718, 1737, 1747, 1803 and 1835, on the issues of missile and nuclear tests by the Democratic People's Republic of Korea and the implementation of safeguards in Iran, as well as UN Security Council resolution 1540 .

Finally, Russia participates in the Hague Code of Conduct against Ballistic Missile Proliferation, formerly known as the International Code of Conduct (AG res.59/91), signed by

\footnotetext{
${ }^{38}$ A nuclear-capable missile was defined as one capable of delivering at least $500 \mathrm{~kg}$ to a range of $300 \mathrm{~km}$ or more.
} 
130 states in $2010 .^{39}$ The HCOC is a political initiative aimed at bolstering efforts to curb ballistic missiles proliferation worldwide and to further delegitimize such proliferation. It is the only normative instrument to verify the spread of ballistic missiles and shows states how they should conduct their trade in missiles. In this vein, it supplements the Missile Technology Control Regime.

In addition to anti-ballistic missile limitations, Russia indeed participates in frameworks relevant to nuclear forensics, which according to the IAEA definition, refers to the analysis of the intercepted illicit nuclear or radioactive material and any associated material to provide evidence for nuclear attribution. Thus, nuclear forensic analysis includes the characterization of the material and correlation with its production history. ${ }^{40}$ Clearly this is one of the more recent ways to combat nuclear terrorism and nuclear material arriving in the hands of terrorists; one of the objectives of the Russian National Security Strategy. ${ }^{41}$ In this vein, Russia co-chairs the Global Initiative to Combat Nuclear Terrorism (GICNT), ${ }^{42}$ for example, and participates in the Nuclear Forensics International Technical Working Group (ITWG). ${ }^{43}$ This informal group was founded as a result of a G-8 initiative after Ottawa Summit (1995) and Moscow Nuclear Security Summit (1996) under the Non-Proliferation Experts Group (NPEG). It reports to G-8 and cooperates closely with the IAEA Office of Nuclear Security.

On a more practical level, Russia, through the Bochvar Institute, in cooperation with the European Commission's Institute for Trans-uranium Elements (ITU), maintains a database of nuclear fuels for the purpose of assisting nuclear forensic investigations.

After running through the major nuclear treaties and regimes in which Russia is part of, we can conclude that its model of insertion results in benefits in its stability and security and is coherent with its political principles and security strategy. In fact, it shows a wide trust in international engagements and multilateral regimes. It is true that the main treaties depended on Russia's agreement but, apart from some exceptions, its process of ratification and implementation has been diligent and guided by good faith. A different question is if, in the current situation, all Russian security interests are covered by those engagements.

Recovering from more than one decade of international decline, Russia is in position to show itself as a strong country, able to protect its security and its interests, as defined in its National Security Strategy. Especially during the Medvedev's presidency, it tried to be present in the international nonproliferation fora and promote a constructive and multilateral approach in part because it does not have the power and capabilities to act unilaterally and in part because nuclear proliferation and issues related to it cannot be solved in isolation. To be marginalized from international nonproliferation regimes is risky for any country as it undermines the ability to impact on international decision-making process or even cause it to

\footnotetext{
${ }^{39}$ UN Security Council resolution 1874 (2009) forbids any launch using ballistic missile technology.

${ }^{40}$ International Atomic Energy Agency: Nuclear Forensics Support, Reference Manual. IAEA Nuclear Security Series \#2, at http://www-pub.iaea.org/MTCD/publications/PDF/Pub1241_web.pdf.

${ }^{41}$ Allison, Graham: "How to Stop Nuclear Terror", Foreign Affairs, (Jan/Feb. 2004), pp. 64-74. Conscious of the problem, Gen. N. Makarov affirmed the willingness of the Army to give consideration to all potential ways in which nuclear weapons may appear in certain states; See "Russian Ballistic Missile Submarine Deal Improbably this Month", Nuclear Threat Initiative, Global Security Newswire (25 April 2012).

${ }^{42}$ Sonderman, Renee: "Global Initiative to Combat Nuclear Terrorism. Efforts in Nuclear Forensics", Global Initiative to Combat Nuclear Terrorism (GICNT) (2011), at http://www.jaea.go.jp/04/np/activity/2011-0202/2011-02-02-23.pdf.

43 Biro, Tamas; Chartier, Bernard; Garrett, Benjamin; Mayer, Klaus and Thompson, Paul: "Building International Cooperation in Nuclear Forensics, “The ITWG”" (2010), at http://www.jaea.go.jp/04/np/activity/2010-10-05/2010-10-05-13.pdf.
} 
be considered a rogue state in terms of nuclear issues.

\section{Russian Position on Iran Nuclear Program}

Since 2006, Iran has continuously defied the UN who had imposed sanctions on Tehran for engaging in activities that could be used to manufacture nuclear weapons. The UN Security Council had asked the country to suspend its uranium enrichment activities until the IAEA confirms that it has not engaged in any unreported nuclear weapons-related activities.

In November 2011, IAEA reported detailed Iranian bomb-making activities. Russia, together with China, resisted imposing more UN sanctions on Iran and instead agreed that the IAEA should issue a strong resolution demanding that Tehran cooperate more with the Agency. Although it seems that neither Western countries nor Tehran are ready to use military power to force the issue, recent months have seen increased speculations concerning a possible attack from Israel.

After a brief negotiating round in a "P5+1" format on April $14^{\text {th }} 2012$, in Istanbul, a new one took place the end of May in Baghdad. With no more concrete developments, even without the limits of the "red lines" on either side, the strictest regime of sanctions was due to enter into force in July. On the $18^{\text {th }}$ and $19^{\text {th }}$ of June 2012, diplomats from Iran and six world powers met again in Moscow for continuing talks. But negotiations failed to defuse the standoff over Tehran's nuclear ambitions. This time, Russian officials, as the conference's hosts, tried to avoid a breakdown of the process. Iranian's request of an international recognition of its right to enrich uranium and of a rollback of the tough sanctions by the European Union and the United States were a "red line" without any noteworthy concession by its side. The result is the breakdown of high-level nuclear talks. ${ }^{44}$

A failure in negotiations, possible anytime if no progress is perceived, would imply a rise in tensions in the region, not convenient for any party, including Russia. The failure of negotiations will improve the possibilities of an attack against Iran even if it is practically impossible until the US elections and the change in Chinese government finish. Some analysts, as well as Israel representatives, consider talks as a time-wasting mechanism for Tehran to look for an extra period to continue its enrichment activities. ${ }^{45}$

Russia's position is against a military attack on Iran that could be catastrophic. They recognize Tehran's right to develop a civilian nuclear program including the uranium enrichment program, but under a complete control by the IAEA. Only under these conditions could the sanctions be suspended. There has been a traditional alliance among Russia, Iran and Armenia under the fear of a Turkish influence in the area and also because the energetic monopoly that Azerbaijan pretends to have. Nuclear cooperation with Tehran began in the late eighties in a cautious manner ${ }^{46}$ as Moscow suspected Iranian intentions of developing a

\footnotetext{
${ }^{44}$ Charlton, Angela and Isachenkov, Vladimir: "EU: Iran nuke meeting to continue on lower level", Associated Press, 19 June 2012. EU High Representative, C. Ashton, announced the indefinite pause in negotiations and said they could be resumed only if the technical Experts meeting in Istanbul ( $3^{\text {rd }}$ July) found enough common ground to warrant such a step.

45 “'Positive' Iranian Nuclear Talks conclude in Istanbul”, Jane's Intelligence Weekly, 16 April 2012.

${ }^{46}$ Even when Russia agreed to build a light-water nuclear reactor, the cooperation was under IAEA safeguards; See Orlov, Vladimir: "Nuclear Programs in North Korea and Iran: Assessing Russia's position", PONARS Policy Memo 178, (Nov. 2000), pp. 1-6.
} 
clandestine nuclear-weapons program and which would be a serious damage to Russian national security.

It is useful to remember that the dynamics introduced by NPR was one of the reasons for changes in Russian arms sales to and support for sanctions against Iran. An Iran with nuclear weapons is contrary to Russian interests but Moscow does not consider this threat imminent or inevitable. This statement is in clear contrast with the one made by the head of the Russian Military General Staff affirming the danger posed by Iran and North Korea. To cope with it, Gen. Makarov said that Russia closely monitors the nuclear program developments of many countries and the analysis conducted together with US confirms that there is a probability that the threat exists, and thus agree on the necessity to create a missile defense system. In contrast, the Defense Ministry had in the past said that neither nation posed an atomic hazard to Russia or European powers as they each lacked atomic armaments as well as vehicles for sending such weapons to targets. ${ }^{47}$ From the previous statements, one can conclude that there is a certain disagreement between government and military staff, perhaps more due to domestic considerations than to objective analysis of the threat in question.

What is perhaps as important as the Iranian threat is that its nuclear activities are driving NATO countries to support missile defense programs that can reduce Russia's nuclear deterrent. ${ }^{48}$ The benefit Russia can obtain from Iran, apart from the important trade partnership, is the assistance in limiting US influence in Central Asia and the Middle East. At the same time, these ties allow Moscow to position itself as a mediator between Iran and the West. Working with Iran can help to address security threats in Afghanistan after the NATO pullout. However, the outcome of the Moscow talks round shows clearly the limitations of Russian power and its limited influence over Iran. Even if Russia tries to show itself as a strong self-sufficient power, a close cooperation with United States and with EU member states is needed to curb the Iranian nuclear program and protect global and regional security.

\section{Russian Approach to North Korea Nuclear Program}

North Korea developed peaceful energy capabilities with the support of the Soviet Union who supplied the country in the sixties with a small enriched-uranium research reactor, which was under the IAEA safeguards. The USSR also facilitated North Korean accession to the Nuclear Non Proliferation Treaty. ${ }^{49}$ In the seventies, Pyongyang decided to create its own nuclear weapons program and started plutonium production alongside the construction of two additional powerful industrial reactors for the reprocessing of irradiated nuclear fuel and the separation of weapons-usable plutonium. In the early nineties, the USSR and later Russia considered North Korean nuclear program as one of the most serious regional nonproliferation challenges as they suspected the Korean regime of being able to manufacture a couple of nuclear warheads. Having no means to impact on North Korea's activities, Russia thought the program was frozen, even if no accurate data was available. Due to its lack of control over the situation, Russia accepted US negotiations with Pyongyang that ended with the signing of the Agreed Framework. Russia exchanged North Korea's nuclear-weapons

\footnotetext{
${ }^{47}$ RIA Novosti, 24 April 2012; See "Russian Ballistic Missile Submarine Deal Improbably this Month", NTI, Global Security Newswire, 25 April 2012.

${ }^{48}$ Weitz, Richard: "Russia's Position on Iranian Nuclear Issue”, 26 January 2012, Center for Political - Military Analysis, Hudson Institute, at http://www.hudson.org/index.cfm?fuseaction=publication details\&id=8681.

${ }^{49}$ See Orlov, op. cit., pp. 1-6.
} 
program for construction of light-water reactors. As a result of the North Korean crisis in the nineties, Russia lost any possibility of participating in the North Korean nuclear market.

As previously mentioned, nuclear proliferation is Russia's main security concern. ${ }^{50}$ North Korea is a border country to the Russian Federation and its nuclear status is considered unacceptable as it represents a violation of the NPT and because of the nuclear tests the country performed. According to Putin's point of view, the solution to the crisis is not military but instead, diplomatic and political means should be prioritized. ${ }^{51}$ The legal framework finds its foundation in the UN Security Council Resolution 1874. Consequently, Russia participates in the Six Party Talks, ${ }^{52}$ together with the US, China, Japan, North Korea and South Korea. It is therefore pertinent to reconstruct the mutual trust in the Korean Peninsula and to profit from the change in Pyongyang leadership.

A special feature of the Russian position is its approach to foreign military interventions, which is considered a precursor for further nuclear proliferation, as having nuclear weapons would shield the states against external intervention. The evidence, in this sense, is that US intervention in Iraq, showing its conventional superiority, gave rise to two different movements: on one side, Libya renounced its mass destruction weapons program and was accepted as a responsible member of the international community; on the other side, the Iranian Ayatollah regime accelerated its nuclear program because having the nuclear weapon would prevent a foreign intervention similar to the one suffered by Saddam Hussein regime. Russia's position, even from the sacred and always invoked principle of national sovereignty, cannot be supportive as it represents a serious risk for international and regional security. On the one side, it is in Russia's interest to unmask and not conceal North Korean plans, protected by China. On the other side, Russia will act taking care that US support to South Korea does not result in American leadership in the area.

\section{Conclusion}

This paper has tried to show Russia as a non-revisionist state concerning international regimes on nonproliferation; non-revisionist state at least in its behavior. Declaring its submission to the rules of International Law, the Russian Federation tries to show itself as a responsible state that adopts a cooperative approach on the topic. Another question would be Russian intentions: from its strategic documents it is easily verifiable that Russia's intention is to change the balance of power in its favor, which according to offensive realism would represent a revisionist attitude. ${ }^{53}$ However, Russia's actual behavior does not reflect revisionism as the state lacks the capabilities to change the current balance of power by itself.

Russia's attitude can be understood from a realistic, but not offensive, approach to nonproliferation issues. ${ }^{54}$ Far from trying to construct a new reality, it carefully attends its national interests that, by this time, are better protected by this kind of normative soft power attitude.

However, two factors can play a negative role on Russian approach: the NATO missile

\footnotetext{
${ }^{50}$ See Putin, op. cit.

${ }^{51}$ Ibid

${ }^{52}$ Its aim is denuclearization under the 2005 Joint Statement of the Six Party Talks.

${ }^{53}$ See Snyder, op. cit., pp. 149-173; Yuan-Kang, op. cit., pp. 173-201.

${ }^{54}$ See Schröder, op. cit.
} 
defense system and the changing leadership in the main nuclear superpowers. Russia's strong opposition to the US-led efforts to build an anti-ballistic missile shield in Eastern Europe and Turkey was one of the reasons for the failure of the NATO-Russia Council on the $18^{\text {th }}$ and $19^{\text {th }}$ of April 2012. ${ }^{55}$ Even if NATO argues that the system will provide protection against nuclear-armed rogue states and is not directed against Russia, Moscow considers the shield as undermining Russia's strategic response capabilities and insists that US should provide written legal guarantees.

It is useful to remember that the now defunct ABM treaty forbade the deployment of radars capable of early warning of strategic ballistic missile attack anywhere other than on the periphery of US or Soviet / Russian territory and oriented outward. The US anti-ballistic missile shield ends with the previous security-logic arguing that the threats today come from a different source. As President Obama offered a closer cooperation with Russia on this topic, Russian grievance is concerned with the level and the content of the proposed cooperation. Whereas Russia wants a unique system, NATO waits on separate systems that exchange information.

As Russia perceives an independent NATO system as an impairment of its nuclear deterrence capacity, President Medvedev announced countermeasures on November 2011, even if negotiations continued. A Conference organized by Russian government in Moscow at the beginning of May 2012 with NATO countries ended with no agreement on the topic. Some high-ranking Russian officials threatened to pull out from the nuclear arms reduction treaty, the New START, signed in April 2010. On its side, the country has toughened its stance on the issue i.e. deploying an Iskander-type air defense system in Kaliningrad. ${ }^{56}$ These measures caused concerns in Baltic States who accused Moscow of using its opposition to the missile shield as a pretext for arms build-up in the region, and which can generate a security dilemma.

The second hypothetical negative factor in Russia's way to nonproliferation is the change in leadership, both in the US and in Russia. Having a clear influence from the US Nuclear Posture Review, the Russian position can change with the replacement of the Russian Presidency as Putin's rhetoric, at least for electoral reasons, was more confrontational. In fact, Russia's relations with NATO are set to be precarious in the coming years judging from Putin's attitude towards it. ${ }^{57}$ Moscow appears to have adopted a more confrontational stance by blocking international gatherings if its demands are not met, even if this approach is hardly likely to be followed if Russia is interested to have its voice heard in the world arena.

As President, Putin has announced Russia's response to the enlargement of the US defense missile system in Europe. According to his statements, in 2020, Russia will have 600 new aircrafts and 1000 helicopters, spending more than four billion rubles just in the modernization of missile-carrier strategic bombers Tu-160 and Tu-95 $\mathrm{MS}^{58}$ that are equipped

\footnotetext{
55 "Russia and NATO divided over Afghanistan withdrawal and missile defence Shield", Jane's Intelligence Weekly, 20 April 2012.

${ }^{56}$ On the other side, maritime based intercontinental ballistic missiles Bulava 30 concluded training phase and was approved by the Army. This new missile (internationally RSM-56, SS NX 30 on NATO classification) run $9.300 \mathrm{~km}$, can hold 10 nuclear heads and avoid anti-missile defense systems.

${ }^{57}$ Putin called NATO "anachronistic", although he highlighted that it is doing an important job in Afghanistan. See "Russia and NATO divided over Afghanistan withdrawal and missile defence Shield", op. cit. However, recent reports on 18 April citing sources close to Russia's Ministry of Defence, say Moscow has halted the delivery of light -arms to Syria as a result of apparent pressure from the United States. It shows Russia's will to outline its leadership and to contribute to the conflict solution by pacific means.

${ }^{58}$ Kolesnikov, A., Kommersant, June 28, 2012.
} 
with a new long-range guided missile. An eventual change at the White House could also enhance the possibilities of misunderstanding between the two powerful nuclear weapon states and consequently have a negative impact on nuclear nonproliferation around the world. The missile-defense issue will likely have to wait until 2013 and the outcome of the US presidential race.

In sum, in Russian nonproliferation policy, normative considerations can be neglected by political and strategic reasons: mainly the permanent goal to be at the same level as the US in terms of military and influential power as well as its aim to be considered a big power. It is in fact a big power but Russian and US leaders have to deal with the urgent issues and think through the future of the bilateral relationship, focusing on what is possible. ${ }^{59}$ Iran and North Korea nuclear challenges are worth a better mutual understanding.

\footnotetext{
${ }^{59}$ D. Trenin, "Putin's National Security Vision", op. cit.
} 
Annex: Russian participation in International engagements and Organisations concerning nonproliferation

\section{RUSSIAN \\ FEDERATION}

\begin{tabular}{|c|c|}
\hline INTERNATIONAL ORGANIZATIONS & STATUS \\
\hline United Nations (UN) & Member \\
\hline Conference on Disarmament iCD I & Member \\
\hline International Atomic Ensrgy Agency (IAEA) & Member \\
\hline Organization for the Probihition of Chemical Weapons (OPCW) & Member \\
\hline $\begin{array}{l}\text { Comprehensise Test Ban Treaty Organization Proparuory } \\
\text { Commission }\end{array}$ & Member \\
\hline G-8 & Member \\
\hline \multicolumn{2}{|l|}{$\begin{array}{l}\text { TREATIES \& AGREEMENTS } \\
\text { Nuclear: }\end{array}$} \\
\hline Nuclear Non-proliferation Treaty (NPT) & State Party \\
\hline Comprehensive Nucleat Tese Ban Treaty (CTBT) & State Party 3 \\
\hline Partial Test Ban Treaty (PTBT) & State Party \\
\hline LAEA Safeguards Agreement & Yes (INFCIRC 327) \\
\hline LAEA Additional Protocol & In force $10 / 16,2007$ \\
\hline Nuclear Safcry Convention & State Party \\
\hline Joint Spent Fuel Management Convention & State Party \\
\hline Convention on the Physical Protsction of Nuclear Material & State Party \\
\hline $\begin{array}{l}\text { Amendment to the Convention on the Physical Protection of Nuclear } \\
\text { Material }\{2005 \text { t }\end{array}$ & State Party \\
\hline Strategic Offensive Reductions Treaty (SORT) & State Party \\
\hline Antarctic Treaty & State Party \\
\hline \multicolumn{2}{|l|}{ Chemical\& Biological: } \\
\hline Chemical Weapons Convention (CWC) & State Party \\
\hline Biological and Toxin Weapons Convention (BTWC) & State Party \\
\hline BTWC Contidence Building Measures (CBMs) ${ }^{4}$ & Submitted \\
\hline Geneya Protocol & State Party \\
\hline \multicolumn{2}{|l|}{ WMD delivery systems: } \\
\hline Hague Code of Conduct against Ballistic Missile Proliferation & State Party \\
\hline \multicolumn{2}{|l|}{ Other: } \\
\hline Proliferation Security Initiative & Participant \\
\hline \multicolumn{2}{|l|}{ NONPROLIFERATION EXPOBT CONTROLS } \\
\hline Zangeer Committec & Member \\
\hline Nuclear Suppliers Grous & Member \\
\hline Australia Group & 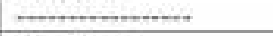 \\
\hline Missile Techinology Control Regime & Member \\
\hline Wassenaar Arrangement & Member \\
\hline \multicolumn{2}{|l|}{ COUNTER-TERRORISM CONVENTIONS \& OBLIGATIONS } \\
\hline Suppression of the Financing of Terrotisnt & State Party \\
\hline Suppression of Terrorast Bombiags & State Party \\
\hline Marking of Plastic Explosives for the Purpose of Detection & State Party \\
\hline Against the Taking of Hostages & State Party \\
\hline Otfences and Costain Other Acts Comanitsul on Bosard.Airstat. & State Party \\
\hline Suppession of Linlayful Scizure of Airctaft & State Party \\
\hline Suppressiga of Lnlawful Acts agaiast the Safety of Civil Ayiation & State Party \\
\hline $\begin{array}{l}\text { Protocel on the Suppression of Unlawfiul Acts of Violence at Airponts } \\
\text { Serving Intemational Civil Aviation }\end{array}$ & State Party \\
\hline $\begin{array}{l}\text { Suppression of Unlagdil Acts against the Safety of Maritime } \\
\text { Navisation }\end{array}$ & State Party \\
\hline $\begin{array}{l}\text { Protocel for the Suppression of Unlanful Acts against the Safety of } \\
\text { Fixed Platforms Located on the Continental Sheif }\end{array}$ & State Party \\
\hline Prevention and Punishment of Crimes against Internationally & State Party \\
\hline
\end{tabular}

Inventory of Intemational Nonproliferation Organizations and Regimes - Center tor Nonprolisteration Studies Last Updated: 11/18/2010 